\title{
TAXONOMIC STUDY ON THE $\varepsilon$-CAPROLACTAM-UTILIZING BACTERIA
}

\author{
HIROSHI IIZUKA, IKUNOSUKE TANABE, TAKASHI FUKUMURA* \\ AND KOICHI KATO*
}

Institute of Applied Microbiology, The University of Tokyo, Tokyo, *Basic Research Laboratories, Toyo Rayon Co., Ltd., Tebiro Kamakura.

(Received November 15, 1966)

\begin{abstract}
The $\varepsilon$-caprolactum-utilizing bacteria were searched. Among 40 authentic strains stored in the IAM Culture Collection, only one strain, Pseudomonas ovalis IAM 1002, was found to utilize $\varepsilon$-caprolactam as a sole sourse of carbon and nitrogen. From the polluted water lines of the Nylon 6 manufacturing plant (Nagoya Plant, Toyo Rayon Co., Ltd., Nagoya) 11 strains of this nature were also isolated and identified. Various characteristics of these bacteria are described.
\end{abstract}

The $\varepsilon$-caprolactam-utilizing bacteria that can utilize $\varepsilon$-caprolactam as a sole source of carbon and nitrogen were isolated from the polluted water lines in the Nylon 6 manufacturing plant, Nagoya, Japan, in 1961. They were identified with the following species:

Achromobacter cycloclastes (GrAy and THORnTon, 1928) Bergey et al., 1930, 1 strain;

Corynebacterium aurantiacum nov. sp., 3 strains;

Corynebacterium roseum nov. sp., 1 strain;

Pseudomonas aeruginosa (SCHROETER, 1872) Migula, 1900, 5 strains;

Pseudomonas desmolytica Gray and Thornton, 1928, 1 strain.

Of the 40 authentic strains of bacteria of the IAM Culture Collection, including 36 species and one variety of 21 genera, only one strain, Pseudomonas ovalis IAM 1002, was able to utilize $\varepsilon$-caprolactam as a sole source of carbon and nitrogen.

Little is known that microorganisms can utilize $\varepsilon$-caprolactam as a sole source of carbon and nitrogen, which is used as a material for its polymer "Nylon 6" and which is dehydrated into 6-aminocaproic acid. KATO and FUKUMURA (1), in 1961, isolated some microorganisms from polluted water lines of the Nylon 6 manufacturing plant, which might assimilate $\varepsilon$-caprolactam well. Eleven strains of these were able to utilize $\varepsilon$-caprolactam as a sole source of carbon and nitrogen, but their ability to utilize 6-aminocaproic acid was different $(1,2)$. They also reported that one of these strains hydrolyzed cyclic and linear oligomers of 6-aminocaproic acid $(3,4)$. 
In the present investigation, the ability to utilize $\varepsilon$-caprolactam of the isolates and many authentic strains of bacteria of the IAM Culture Collection was examined.

\section{MATERIALS AND METHODS}

Microorganisms. Isolation of the $\varepsilon$-caprolactam-utilizing bacteria was carried out by the plating method on a mineral salts agar containing $\varepsilon$-caprolactam as a sole source of carbon and nitrogen at $37^{\circ}$ for 2 weeks. Typical isolates consisted of eleven strains of bacteria: $\mathrm{Y}-1, \mathrm{Y}-2, \mathrm{Y}-3, \mathrm{Y}-4, \mathrm{Y}-5$, $\mathrm{W}-1, \mathrm{~W}-2, \mathrm{~B}-1, \mathrm{~B}-2, \mathrm{~B}-3$ and $\mathrm{R}$. The medium for isolation was composed of: $\varepsilon$-caprolactam, $5 \mathrm{~g}$; yeast extract, $1 \mathrm{~g} ; \mathrm{K}_{2} \mathrm{HPO}_{4}, 1.3 \mathrm{~g} ; \mathrm{KH}_{2} \mathrm{PO}_{4}, 0.3 \mathrm{~g}$; $\mathrm{MgSO}_{4} \cdot 7 \mathrm{H}_{2} \mathrm{O}, 0.5 \mathrm{~g} ; \mathrm{MnCl}_{2} \cdot 4 \mathrm{H}_{2} \mathrm{O}, 0.02 \mathrm{~g} ; \mathrm{FeSO}_{4} \cdot 7 \mathrm{H}_{2} \mathrm{O}, 0.02 \mathrm{~g}$; deionized water, $600 \mathrm{ml}$; tap water, $400 \mathrm{ml}$; pH 7.2.

For the comparative study on $\varepsilon$-caprolactam-utilizing bacteria, 40 authentic strains of bacteria of the IAM Culture Collection in the Institute of Applied Microbiology, University of Tokyo, were employed (Table 1).

Morphological characteristics. The microorganisms were stained by HUCKER's modification of the Gram staining (5) after incubation for $18 \mathrm{hr}$, $60 \mathrm{hr}$, and 12 days at $37^{\circ}$ on nutrient agar slants, and their cell sizes were also measured. Pleomorphic strains were stained by the same method after incubation for 3 days and 7 days at $37^{\circ}$ on $10 \%$ lithium chloride-nutrient agar slants (5) and on 10\% lithium chloride-nutrient agar slants, respectively. Gram-positive strains were stained by Ziehl-Neelsen method of acid-fast staining after incubation for $48 \mathrm{hr}$ on nutrient agar slants (5). The isolates were examined for motility in a soft agar. Only motile strains were stained for flagella; the technique was based on the method of SUGAWARA and NishizAWA's flagella staining (6). Motile organisms were also examined with an electron microscope.

Nutrient agar is composed of: beef extract, $3 \mathrm{~g}$; Polypepton, $5 \mathrm{~g} ; \mathrm{NaCl}$ $3 \mathrm{~g}$; agar, $20 \mathrm{~g}$; tap water, 1 liter; $\mathrm{pH} 7.2$, and in some case $10 \%$ lithium chloride solution is added to nutrient agar at the ratio of $0,1,2$ or $3 \mathrm{ml} / 5$ $\mathrm{ml}(10 \% \mathrm{LiCl}$-nutrient agar). Yeast extract-malt extract agar (7) is composed of: yeast extract, $4 \mathrm{~g}$; malt extract, $10 \mathrm{~g}$; glucose, $4 \mathrm{~g}$; distilled water, 1 liter $(\mathrm{pH} 7.2)$, and $10 \%$ lithium chloride-yeast extract-malt extract agar is prepared in the same way as in 10\% lithium chloride-nutrient agar. Soft agar is composed of: Polypepton, 0.05, 0.25, or $1 \mathrm{~g}$; agar, 3 or $5 \mathrm{~g}$; 1 liter of mineral salts solution $\left(\mathrm{K}_{2} \mathrm{HPO}_{4}, 0.8 \mathrm{~g} ; \mathrm{KH}_{2} \mathrm{PO}_{4}, 0.2 \mathrm{~g} ; \mathrm{MgSO}_{4} \cdot 7 \mathrm{H}_{2} \mathrm{O}, 0.2 \mathrm{~g} ; \mathrm{CaCl}_{2} \cdot 2 \mathrm{H}_{2} \mathrm{O}\right.$, $0.05 \mathrm{~g} ; \mathrm{FeSO}_{4} \cdot 7 \mathrm{H}_{2} \mathrm{O}, 0.025 \mathrm{~g} ; \mathrm{MnSO}_{4} \cdot 4 \mathrm{H}_{2} \mathrm{O}, 0.0005 \mathrm{~g} ; \mathrm{NaCl}, 0.2 \mathrm{~g} ; \mathrm{Na}_{2} \mathrm{MoO}_{4}$, $0.0005 \mathrm{~g}$; $\mathrm{NaWO}_{4}, 0.0005 \mathrm{~g}$; distilled water, 1 liter); $\mathrm{pH}$ being adjusted to 7.2.

Cultural characteristics. The colony appearance was noted after 7 days. Appearances of 7-day cultures in a nutrient broth and on a nutrient agar slant incubated at $37^{\circ}$ were recorded. The chromogenesis was recorded with 7-day cultures on nutrient agar slants and on $30 \%(\mathrm{v} / \mathrm{v})$ skim milknutrient agar slants incubated at $37^{\circ}(8)$. 
Physiological characteristics. A standard inoculum for all the tests was one loopful of a 5-day $\varepsilon$-caprolactam agar culture, and all the test media were incubated at $37^{\circ}$.

The temperature range of growth was observed on the multiplication of microorganisms on nutrient agar slants at $10,20,30,37$ and $42^{\circ}$, and the incubation periods extended from 1 to 2 weeks, depending on the temperature of incubation. In order to observe inorganic nitrogen utilization, cultures were incubated for 14 days in a medium composed of: mineral salts solution, 1 liter; glucose, $10 \mathrm{~g}$; $\left(\mathrm{NH}_{4}\right)_{2} \mathrm{SO}_{4}, 2 \mathrm{~g}$; yeast extract, $0.1 \mathrm{~g}(\mathrm{pH} 7.2)$. Each culture was examined regularly for growth. Nitrogen fixation was observed for one month on the multiplication of microorganisms in a medium composed of: mineral salts solution, 1 liter; glucose, $10 \mathrm{~g}(\mathrm{pH} 7.2)$. Reduction of nitrate to nitrite was detected by the Griess reagents after incubation for 7 days in a nitrate broth (beef extract, $3 \mathrm{~g}$; Polypepton, $5 \mathrm{~g} ; \mathrm{KNO}_{3}, 1 \mathrm{~g}$; distilled water, 1 liter ( $\mathrm{pH} \mathrm{7.0)} \mathrm{(5).} \mathrm{Zinc} \mathrm{powder} \mathrm{was} \mathrm{used} \mathrm{to} \mathrm{test} \mathrm{for} \mathrm{false} \mathrm{negatives.} \mathrm{Am-}$ monia production was tested with Bromcresol Purple (BCP) for changes in the appearance of the test medium (mineral salts solution, 1 liter; Polypepton, $5 \mathrm{~g} ; 1.6 \%$ BCP alcoholic solution, $1 \mathrm{ml} ; \mathrm{pH} 7.2)$. Hydrolysis of urea was detected with Bromthymol Blue (BTB) by its colour change within 2 weeks in the appearance of the test medium composed of: mineral salts solution, 1 liter; yeasts extract, $1 \mathrm{~g}$; $\mathrm{Na}_{2} \mathrm{CO}_{3}, 0.1 \mathrm{~g}$; urea (urea solution was filtersterilized and added aseptically to the test tubes with broth including other ingredients after they had been autoclaved), $10 \mathrm{~g} ; 1.6 \%$ BTB alcoholic solution, $1 \mathrm{ml} ; \mathrm{pH}$ not adjusted. To ensure that the alkalinity produced was due to hydrolysis of urea, a control medium without urea was inoculated with the urease-positive strain. Those strains which gave a markedly more alkaline reaction only in the urea medium were considered to be true positives. In order to detect gelatin liquefaction, gelatin medium (beef extract, $3 \mathrm{~g}$; Polypepton, $5 \mathrm{~g}$; $\mathrm{NaCl}, 3 \mathrm{~g}$; gelatin, $150 \mathrm{~g}$; distilled water, 1 liter; $\mathrm{pH} 7.0$ ) was inoculated and incubated for a month at $20^{\circ}$, the appearance and extent of liquefaction being noted at regular intervals (5). The method of HUGH and LEIFSON was used to determine glucose utilization, whether glucose was used oxidatively or fermentatively. HUGH and LEIFsON's test medium consists of: Polypepton, $2 \mathrm{~g}$; $\mathrm{NaCl}, 5 \mathrm{~g}$; $\mathrm{K}_{2} \mathrm{HPO}_{4}, 0.3 \mathrm{~g}$; glucose, $10 \mathrm{~g}$; BTB, $0.003 \mathrm{~g}$; agar, $3 \mathrm{~g}$; distilled water, 1 liter; $\mathrm{pH} 7.1(9)$. Production of acid and gas from carbohydrate was observed for 14 days in a medium composed of: test carbohydrate, $5 \mathrm{~g}$; Polypepton, $2 \mathrm{~g}$; $\mathrm{NaCl}, 5 \mathrm{~g} ; \mathrm{K}_{2} \mathrm{HPO}_{4}, 0.3 \mathrm{~g} ; \mathrm{BTB}, 0.016 \mathrm{~g}$; agar, $3 \mathrm{~g}$; distilled water, 1 liter; $\mathrm{pH}$ 7.0. The carbohydrates employed were $\mathrm{D}$ xylose, D-glucose, sucrose, maltose, lactose, D-mannitol, and salicin. Starch hydrolysis was detected with a drop of iodine solution for the presence of starch breakdown products after incubation for 7 and 14 days in the starch broth (beef extract, $3 \mathrm{~g}$; Polypepton, $5 \mathrm{~g} ; \mathrm{NaCl}, 3 \mathrm{~g}$; soluble starch, $2 \mathrm{~g}$; distilled water, 1 liter; $\mathrm{pH}$ 7.2). Organic acid utilization was observed on the multiplication of microorganisms after incubation for 7 days in the test 
medium containing a test organic acid as a sole source of carbon; the strains which showed growth after two serial subcultures were recorded as positives. The test medium was composed of: test organic acid, 3 to $10 \mathrm{~g}$; yeast extract, $0.1 \mathrm{~g}$; $\left(\mathrm{NH}_{4}\right)_{2} \mathrm{SO}_{4}, 1 \mathrm{~g}$; mineral salts solution, 1 liter; $\mathrm{pH} 7.2$. The organic acids employed were citric acid, $p$-hydroxy-benzoic acid, and gluconic acid. Hydrogen sulfide formation was detected after incubation for 14 days in the test medium (Polypepton, $2 \mathrm{~g}$; $\varepsilon$-caprolactam, $3 \mathrm{~g}$; L-cystine, $100 \mathrm{mg}$; lead acetate, $200 \mathrm{mg}$; sodium thiosulfate, $80 \mathrm{mg}$; agar, $15 \mathrm{~g}$; distilled water, 1 liter; $\mathrm{pH}$ 7.2; lead acetate and sodium thiosulfate were added to the medium after the agar had melted and the medium was then autoclaved). Indole formation was determined by KovACS' reagent in cultures incubated for 7 days in peptone water (Polypepton, $10 \mathrm{~g}$; DL-tryptophan, $100 \mathrm{mg} ; \mathrm{KNO}_{3}, 0.1 \mathrm{~g} ; \mathrm{NaCl}$, $5 \mathrm{~g}$; distilled water, 1 liter; $\mathrm{pH} 7.0)$ (5). In order to detect acetylmethylcarbinol and acid produced, Voges-ProskAUER and Methyl Red tests were carried out after incubation for 10 days in glucose phosphate broth (Polypepton, $7 \mathrm{~g}$; glucose, $5 \mathrm{~g}$; $\mathrm{K}_{2} \mathrm{HPO}_{4}, 5 \mathrm{~g}$; distilled water, 1 liter; $\mathrm{pH} 7.2$ ) (5). Catalase formation was tested by adding hydrogen peroxide to 3-day cultures on nutrient agar slants (beef extract, $3 \mathrm{~g}$; Polypepton, $5 \mathrm{~g}$; $\mathrm{NaCl}, 3 \mathrm{~g}$; agar $20 \mathrm{~g}$; tap water, 1 liter; $\mathrm{pH} 7.2$ ) (5). For oxidase formation the method of Kovacs was employed on similar cultures (10). Decomposition of cellulose was observed on disintegration of paper strips at regular intervals for 6 weeks in a medium consisting of: cellulose strip, 1 by $8 \mathrm{~cm}, 1$ piece; yeast extract, $0.1 \mathrm{~g}$; Polypepton, $2 \mathrm{~g}$; mineral salts solution, 1 liter; $\mathrm{pH}$ 7.2. Decomposition of agar was observed on lysis of agar at regular intervals for 6 weeks on a medium consisting of: agar, $20 \mathrm{~g}$; yeast extract, $0.1 \mathrm{~g}$; Polypepton, $2 \mathrm{~g}$; mineral solution, 1 liter; $\mathrm{pH}$ 7.2. Fat hydrolysis was determined by ANDERSON's simple triglyceride technique. The test medium consisted of: tributyrine, $10 \mathrm{~g}$, or triolein, $5 \mathrm{~g}$; $\left(\mathrm{NH}_{4}\right)_{2} \mathrm{SO}_{4}, 2 \mathrm{~g} ; \mathrm{K}_{2} \mathrm{HPO}_{4}, 1 \mathrm{~g} ; \mathrm{MgSO}_{4} \cdot 7 \mathrm{H}_{2} \mathrm{O}, 0.5 \mathrm{~g}$; glucose, $10 \mathrm{~g}$; agar, $20 \mathrm{~g}$; distilled water, 1 liter; $\mathrm{pH}$ not adjusted (11). Action on litmus milk and BCP milk was observed at regular intervals for 6 weeks on changes in the appearance of litmus milk (skim milk, 1 liter; litmus, $3 \mathrm{~g} ; \mathrm{pH}$ 7.0) and that of BCP milk (skim milk, 1 liter; $1.6 \%$ BCP alcoholic solution, $1 \mathrm{ml} ; \mathrm{pH} \mathrm{7.0)}$. Utilization of $\varepsilon$-caprolactam and the related compounds was observed after cultivation of organisms for 14 days on media containing, respectively, $\varepsilon$-caprolactam, lysine, and adipic acid $+\left(\mathrm{NH}_{4}\right)_{2} \mathrm{SO}_{4}$ as a sole source of carbon and nitrogen; the strains which showed growth after two serial subcultures were recorded as positives. The test medium consisted of: test compound, $5 \mathrm{~g}$; yeast extract, $0.1 \mathrm{~g}$; mineral salts solution, 1 liter; $\mathrm{pH}$ 7.2.

\section{RESULTS}

\section{Determination of $\varepsilon$-caprolactam-utilizing bacteria}

Eleven isolates were identified with Achromobacter cycloclastes, Pseudomonas aeruginosa, Pseudomonas desmolytica, and two new species of Cory- 
Table 1. Distribution of bacteria able to utilize $\varepsilon$-caprolactam as a sole source of carbon and nitrogen in the IAM Culture Collection.

Able to grow on the $\varepsilon$-caprolactam medium:

Pseudomonas ovalis IAM 1002

Unable to grow on the $\varepsilon$-caprolactam medium:

Achromobacter cycloclastes IAM 1013

Aerobacter aerogenes IAM 1019

Aerobacter cloacae IAM 1020

Aeromonas hydrophila IAM 1018

Agrobacterium tumefaciens IAM 1037

Alcaligenes faecalis IAM 1015

Arthrobacter simplex IAM 1660

Bacillus cereus IAM 1029

Bacillus megaterium IAM 1030

Bacillus sphaericus IAM 1286

Bacillus subtilis IAM 1026

Brevibacterium ammoniagenes IAM 1641

Brevibacterium helvolum IAM 1637

Brevibacterium imperiale IAM 1654

Corynebacterium equi IAM 1038

Corynebacterium fasciens IAM 1079

Erwinia carotovora IAM 1024

Escherichia coli IAM 1016, IAM 1101, IAM 1204

Escherichia coli var. communior IAM 1272

Flavobacterium arborescens IAM 1100

Flavobacterium rigense IAM 1238

Flavobacterium suaveolens IAM 1131

Flavobacterium sulfureum IAM 1252

Micrococcus luteus IAM 1097

Micrococcus roseus IAM 1295

Protaminobacter alboflavus IAM 1040

Proteus vulgaris IAM 1025

Pseudomonas aeruginosa IAM 1007, IAM 1215

Pseudomonas dacunhae IAM 1048

Pseudomonas fluorescens IAM 1057

Serratia marcescens IAM 1021

Staphylococcus aureus IAM 1011

Vibrio metschnikovii IAM 1039

Xanthomonas oryzae IAM 1298

Xanthomonas pruni IAM 1299

Chromobacterium violaceum IAM 1929 
nebacterium (see "Descriptions of Strains").

Distribution of the ability to utilize e-caprolactam as a sole source of carbon and nitrogen in the IAM Culture Collection

In order to investigate the distribution of the microorganisms in the IAM Culture Collection which are able to utilize $\varepsilon$-caprolactam as a sole source of carbon and nitrogen, 40 IAM authentic strains of bacteria were served for the test. There was only one strain, Pseudomonas ovalis IAM 1002 , that gave a positive result among the IAM authentic strains of bacteria employed (Table 1). These results point out that the ability of the microorganisms to utilize $\varepsilon$-caprolactam is not widely distributed in nature.

\section{DESCRIPTIONS OF STRAINS}

Achromobacter cycloclastes (GRAY and THORnTON, 1928) Bergey et al., 1930.

Strain: W-2.

Strain W-2 is not similar to any species listed in Bergey's Manual (12), but in cell morphology, motility and flagellate, appearance of the colony, acid formation (glucose utilization), and temperature range of growth, the closest species in the genus Achromobacter and the genus Alcaligenes is Achromobacter cycloclastes, although strain W-2 has no ability to reduce nitrate (Fig. 1a, 2a).

Properties, except those in Bergey's Manual: Inorganic nitrogen not utilized, but glutamate utilized as a sole source of nitrogen. No growth on the nitrogen-free medium. $\varepsilon$-Caprolactam and adipic acid $+\left(\mathrm{NH}_{4}\right)_{2} \mathrm{SO}_{4}$ utilized as a sole source of carbon and nitrogen. Ammonification. Urease negative. Oxidase positive. Citrate utilized as a sole source of carbon, but not $p$ hydroxybenzoate. Potassium gluconate utilized, but a slime not produced. Catalase positive. Indole not produced. Hydrogen sulfide not produced. Acetylmethylcarbinol not produced. Non-cellulolytic. Non-agarolytic. Nonlipolytic.

Source: The polluted water lines of the Nylon 6 manufacturing plant (Nagoya plant, Toyo Rayon Co., Ltd.), Nagoya, Japan. 1961.

Corynebacterium aurantiacum nov. sp.

au. ran. ti'a. cum M. L. adj. aurantiacus orange-colored.

Strains: B-1, B-2, B-3.

Type strain: Corynebacterium aurantiacum B-1 (Fig. 1b, 3a, 3b).

A few branching cells were found on the smears of these strains and, when lithium chloride was added to the culture medium, more branching cells were observed. Therefore, these strains are considered to belong to the family Corynebacteriaceae, although they were similar to the genus Brevibacterium in many properties. Furthermore, these strains, having no arthrospore, being always gram-positive during the cultural stage, and producing an orange-colored pigment, are not species of the genus Arthro- 

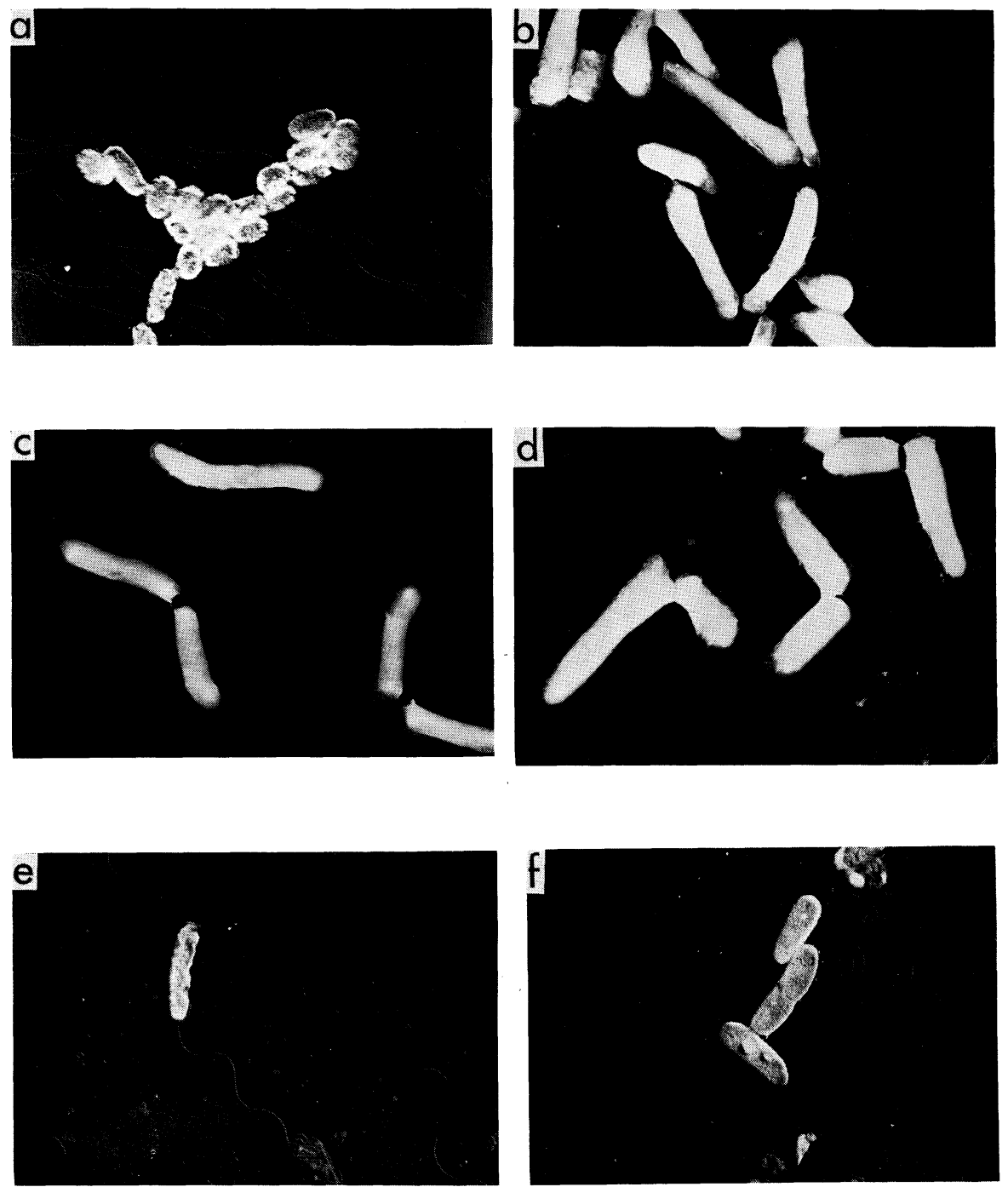

Fig. 1. Electron micrographs of $\varepsilon$-caprolactam-utilizing bacteria. Cells grown on $\varepsilon$-caprolactam agar slant for $18 \mathrm{hr}$ at $37^{\circ}$.

a: Achromobacter cycloclastes W-2.

b: Corynebacterium aurantiacum B-1.

c: Corynebacterium aurantiacum B-2.

$d$ : Corynebacterium roseum $\mathrm{R}$.

$e$ : Pseudomonas aeruginosa $\mathrm{Y}-1$.

$f$ : Pseudomonas desmolytica $\mathrm{W}-1$. 
bacter, but should be considered as freely living corynebacteria. The closest of the species listed in Bergey's Manual (12) is Corynebacterium pseudotuberculosis, which is different from these strains in respect to the source and habitat of microorganisms on which its species name would be based. Accordingly, these strains should be presented with a new species name as a new species of the genus Corynebacterium (Fig. 1c, 3c, 3d, 3e).

Rods, 0.5 to 0.7 by 0.7 to $3.0 \mathrm{M}$, coccoid and ellipsoidal cells to rather long and sometimes branched forms. Wedge and club forms are common. Picket formations due to snapping division. Gram positive. Non-motile. Not acid fast.

Nutrient broth: Turbid with membrane. Nutrient agar plate: Circular colonies, convex, dry, undulate. Pale orange to reddish orange, but yellowish gray according to the medium.

Temperature relations: Optimum, $42^{\circ}$. Range for growth, $20^{\circ}$ to $42^{\circ}$. Inorganic nitrogen may not be utilized, but glutamate a little as a sole source of nitrogen. No growth on the nitrogen-free medium. $\varepsilon$-Caprolactam utilized (B-2) or not (B-1, B-3) as a sole source of carbon and nitrogen. Lysine not utilized. Adipic acid utilized well. Ammonification. Urease positive. Oxidase negative. No acid from glucose, lactose, sucrose, maltose, xylose, mannitol, and salicin. Citrate and p-hydroxybenzoate utilized as a sole source of carbon. Potassium gluconate utilized a little, but a slime not produced. Catalase positive. Aerobic. Nitrates slightly reduced. Indole not produced. Gelatin not liquefied. Hydrogen sulfide not produced. Acetylmethylcarbinol not produced. Starch hydrolysed. Non-cellulolytic. Nonagarolytic. Non-lipolytic. Milk: Alkaline.

Source: The polluted water lines of the Nylon 6 manufacturing plant, (Nagoya plant, Toyo Rayon Co., Ltd.), Nagoya, Japan. 1961. Type strain has been deposited in the IAM Culture Collection, the Institute of Applied Microbiology, University of Tokyo, Japan.

Corynebacterium roseum nov. sp.

ro'se. um L. adj. roseus rose-colored.

Strain: R.

Type strain: Corynebacterium roseum $\mathrm{R}$ (Fig. 1d, 3f, 3g, 3h, 3i).

Corynebacterium equi is the closest to this strain of the species listed in Bergey's Manual, but by the same reason as in the case of Corynebacterium aurantiacum this strain should be identified as a new species of Corynebacterium.

Rods, 0.5 to 0.6 by 0.7 to $3.0 \mu$ coccoid and ellipsoidal cells to rather long and sometimes branched forms. Wedge and club forms are common. Picket formations due to snapping division. Gram positive. Non-motile. Not acid fast.

Nutrient broth: Turbid, granular sediment according to the medium. Pellicle formed. Nutrient agar plate: Circular colonies, convex, dry, undulate. Pale orange, light yellowish orange, pale pink, reddish orange and light yel- 

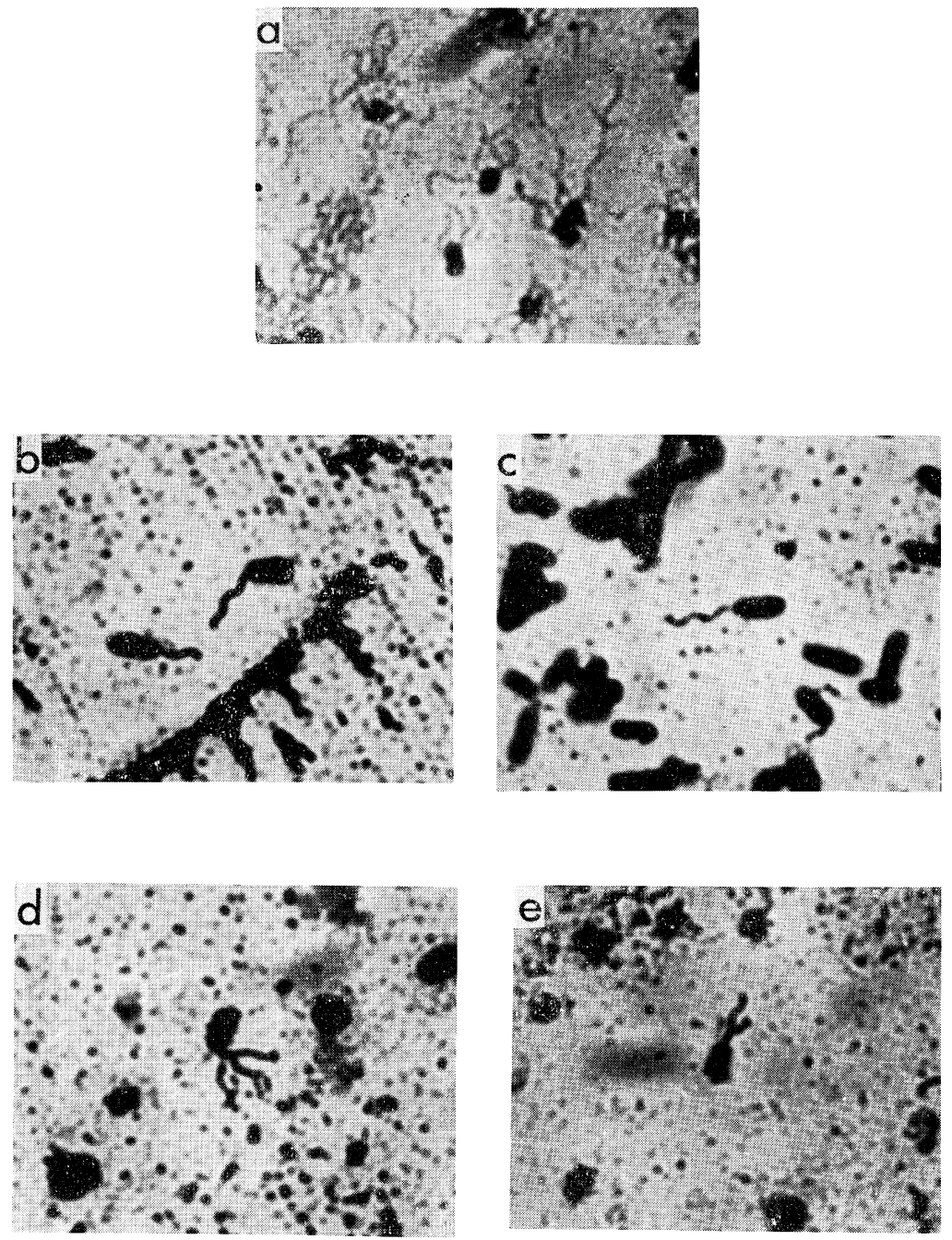

Fig. 2. Flagellation of $\varepsilon$-caprolactam-utilizing bacteria. Cells grown on nutrient agar slant for $18 \mathrm{hr}$ at $37^{\circ}$. Stained by the method of SugAwARA and NisHizAwA's flagella stain.

a : Peritrichous flagellation of Achromobacter cycloclastes W-2.

$\mathrm{b}$ and c: Polar flagellation of Pseudomonas aeruginosa $\mathrm{Y}-1$.

$\mathrm{d}$ and e: Polar (lophotrichous) flagellation of Pseudomonas desmolytica W-1. 
lowish red.

Temperature relations: Optimum, $37^{\circ}$. Range for growth, $20^{\circ}$ to $42^{\circ}$. Inorganic nitrogen not utilized, but glutamate a little as a sole source of nitrogen. Slight growth on the nitrogen-free medium. $\varepsilon$-Caprolactam and adipic acid $+\left(\mathrm{NH}_{4}\right)_{2} \mathrm{SO}_{4}$ utilized as a sole source of carbon and nitrogen. Lysine not utilized. Ammonification. Urease negative. Oxidase negative. No acid from glucose, lactose, maltose, xylose, and salicin, but a slight acid from sucrose and mannitol. Citrate and $p$-hydroxybenzoate utilized as a sole source of carbon. Potassium gluconate utilized a little, but a slime not produced. Catalase positive. Aerobic. Nitrates reduced to nitrites. Indole not produced. Gelatin not liquefied. Hydrogen sulfide not produced. Acetylmethylcarbinol not produced. Starch hydrolyzed. Non-cellulolytic. Non-agarolytic. Nonlipolytic. Milk: Alkaline.

Source: The polluted water lines of the Nylon 6 manufacturing plant (Nagoya plant, Toyo Rayon Co., Ltd.), Nagoya, Japan. 1961. Type strain has been deposited in the IAM Culture Cellection, the Institute of Applied Microbiology, University of Tokyo, Japan.

Fig. 3. Pleomorphisms of $\varepsilon$-caprolactam-utilizing bacteria.

a: Nutrient agar slant for $18 \mathrm{hr}$ at $37^{\circ}$. Normal cells and snapping division. (Corynebacterium aurantiacum B-1)

b: $10 \% \mathrm{LiCl}(1 \mathrm{ml})$-nutrient agar slant for 3 days at $37^{\circ}$. Branching cells. (Corynebacterium aurantiacum B-1)

c: Nutrient agar slant for $18 \mathrm{hr}$ at $37^{\circ}$. Normal cells and snapping division. (Corynebacterium aurantiacum B-2)

$\mathrm{d}$ : Nutrient agar slant for $18 \mathrm{hr}$ at $37^{\circ}$. Branching cells. (Corynebacterium aurantiacum $\mathrm{B}-2$

e: $10 \% \mathrm{LiCl}(1 \mathrm{ml})$-yeast extract-malt extract agar slant for 2 days at $37^{\circ}$. Branching cells. (Corynebacterium aurantiacum B-3)

f: Nutrient agar slant for $18 \mathrm{hr}$ at $37^{\circ}$. Snapping division and picket formation. (Corynebacterium roseum $\mathrm{R}$ )

g: Nutrient agar slant for $18 \mathrm{hr}$ at $37^{\circ}$. Branching cells. (Corynebacterium roseum $\mathrm{R}$ )

h: $10 \% \mathrm{LiCl}(3 \mathrm{ml})$-nutrient agar slant for 3 days at $37^{\circ}$. Branching cells. (Corynebacterium roseum $\mathrm{R}$ )

i: $10 \% \mathrm{LiCl}(2 \mathrm{ml})$-yeast extract-malt extract agar slant for 2 days at $37^{\circ}$. Branching cells. (Corynebacterium roseum $\mathrm{R}$ )

j: $10 \% \mathrm{LiCl}(1 \mathrm{ml})$-nutrient agar slant for 3 days at $37^{\circ}$. Bulging cells and elongation of cells. (Pseudomonas aeruginosa $\mathrm{Y}-5$ )

$\mathrm{k}$ : Nutrient agar slant for $18 \mathrm{hr}$ at $37^{\circ}$. Normal cells. (Pseudomonas desmolytica $\mathrm{W}-1)$

1: $10 \% \mathrm{LiCl}(1 \mathrm{ml})$-nutrient agar slant for 3 days at $37^{\circ}$. Vibrio-like cells. (Pseudomonas desmolytica W-1)

Stained by the cell wall stain (5) (a-i and k) or by Hucker's modification of Gram's method (i and 1 ). 

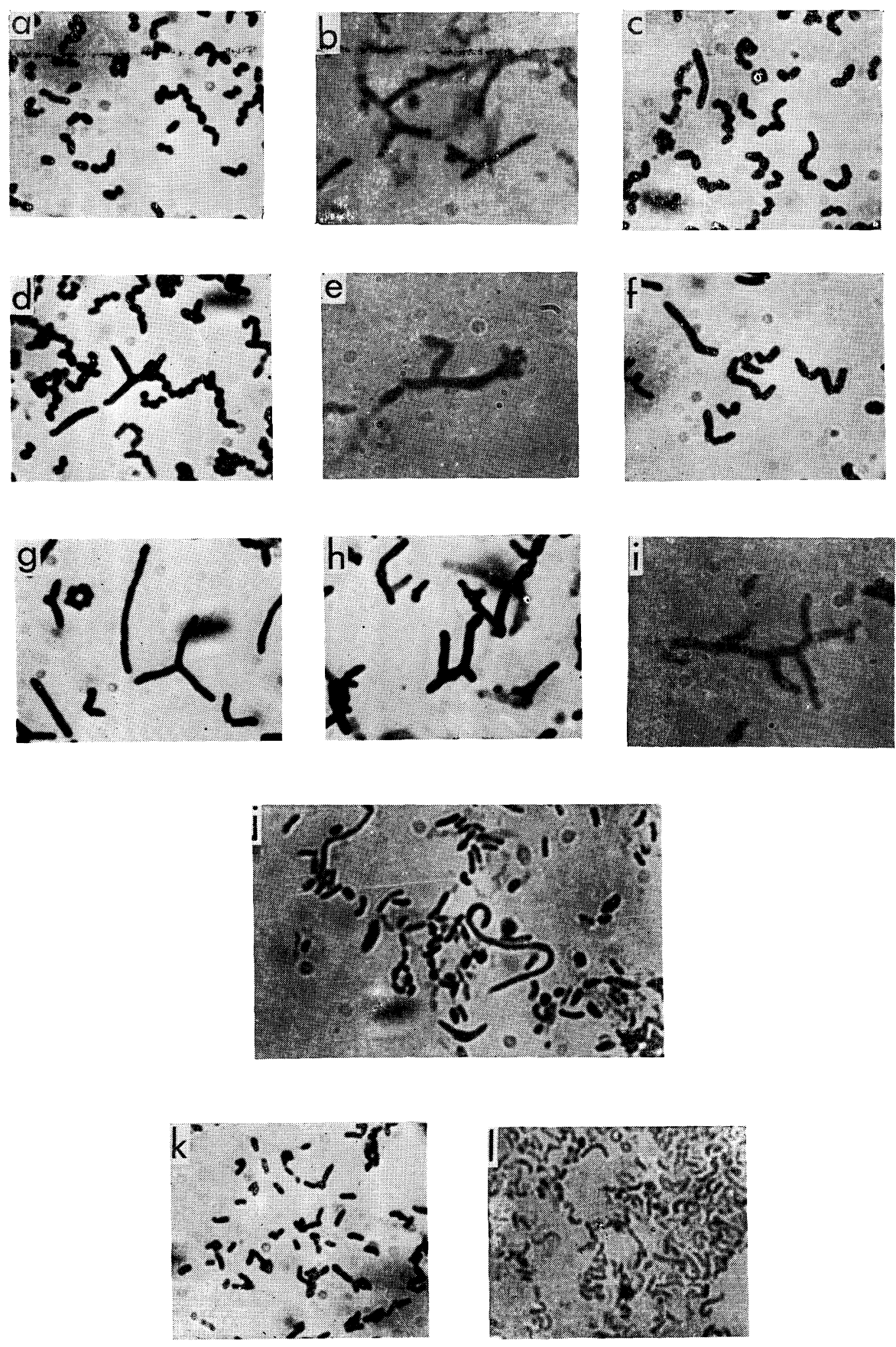

Fig. 3. 
Pseudomonas aeruginosa (Schroeter, 1872) Migula, 1900.

Strains: Y-1, Y-2, Y-3, Y-4, Y-5.

These strains are considered to be Pseudomonas aeruginosa, failing to produce pyocyanin and milk reaction, because they 1) produce a diffusible pigment, 2) liquefy gelatin, 3) are polarly flagellate, and 4) grow readily at $42^{\circ}$ on a nutrient agar slant. These strains were divided into two groups with the colony form: 1) strains, forming only spreading colonies (Y-3 and $\mathrm{Y}-4$ ), and 2) strains, forming both convex colonies and spreading colonies $(\mathrm{Y}-1, \mathrm{Y}-2$ and $\mathrm{Y}-5)$. By the repeated plating method in order to obtain one cell colonies originating from one cell colony, the former strain produced always only spreading colonies, while the latter produced both convex colonies and spreading colonies. The spreading colonies derived from convex colonies produced always only spreading colonies by plating again. These strains should belong to the same species, because of the similar physiological properties, differing in the colony form (Fig. 1e, 2b, 2c, 3j).

Properties, except these in Bergey's Manual: Inorganic nitrogen glutamate utilized as a sole source of nitrogen. No growth on the nitrogen-free medium. $\varepsilon$-Caprolactam, lysine and adipic acid $+\left(\mathrm{NH}_{4}\right)_{2} \mathrm{SO}_{4}$ utilized as a sole source of carbon and nitrogen. Ammonification. Urease negative. Oxidase positive. Glucose used oxidatively. Citrate and $p$-hydroxybenzoate utilized as a sole source of carbon, but potassium gluconate not utilized. Catalase positive. Hydrogen sulfide not produced. Acetylmethylcarbinol not produced. Starch not hydrolyzed. Non-cellulolytic. Non-agarolytic. Non-lipolytic.

Source: The polluted water lines of the Nylon 6 manufacturing plant (Nagoya plant, Toyo Rayon Co., Ltd.), Nagoya, Japan. 1961.

Pseudomonas desmolytica Gray and Thornton, 1928

Strain: W-1.

According to Bergey's Manual (12), strain W-1 should be identified with Pseudomonas desmolytica, although it is close to Pseudomonas arvilla in many characteristics except the ability to reduce nitrates. This strain produced many vibrio-like cells, when it was cultured on $10 \%$ lithium chloride-nutrient $(1 \mathrm{ml})$ agar slant for 3 days at $37^{\circ}$. This fact shows that this strain may be composed of essentially slightly curved cells and is one of closer pseudomonads to the genus Vibrio (Fig. 1f, 2d, 2e, 3k, 3l).

Properties, except those in Bergey's Manual: Inorganic nitrogen not utilized as a sole source of nitrogen, but glutamate utilized. Slight growth on the nitrogen-free medium. $\varepsilon$-Caprolactam, lysine and adipic acid $+\left(\mathrm{NH}_{4}\right)_{2} \mathrm{SO}_{4}$ utilized as a sole source of carbon and nitrogen. Ammonification. Urease positive. Oxidase positive. Glucose used oxidatively. Citrate and $p$-hydroxybenzoate not utilized as a sole source of carbon. Potassium gluconate utilized, but a slime not produced. Catalase positive. Indole not produced. Hydrogen sulfide not produced. Acetylmethylcarbinol not produced. Noncellulolytic. Non-agarolytic. Non-lipolytic. Milk: No change. 
Source: The polluted water lines of the Nylon 6 manufacturing plant (Nagoya plant. Toyo Rayon Co., Ltd.), Nagoya Japan. 1961.

\section{REFERENCES}

1) K. Kato and T. Fukumura: Chem. Ind. (London), 1146 (1962).

2) K. Kato and T. Fukumura: Kagaku, 32, 430 (1962), in Japanese

3) T. Fukumura, H. Shimizu and K. Kato: Symposium on Enzyme Chemistry, 307 (1964), in Japanese.

4) T. Fukumura and K. Kato: Symposium on Enzyme Chemistry, 305 (1965), in Japanese.

5) Society of American Bacteriologists: Manual of Methods for Pure Culture Study of Bacteria (1954).

6) Department of Agricultural Chemistry, University of Tokyo: Experimental Agricultural Chemistry, 177 (1956), in Japanese.

7) T. G. Pridham: Antibiotic Annual, 1956-1957, 947 (1957).

8) J. M. Shewan: Symposium on Marine Microbiology, 499 (1962).

9) R. Hugh and E. Leifson: J. Bact., 66, 24 (1953).

10) N. Kovacs: Nature, 178, 703 (1956).

11) G. A. DE VRIES: Contribution to the Knowledge of the Genus Cladosporium Link ex Fr. Baarn, Helland (1952).

12) R. S. Breed: Bergey's Manual of Determinative Bacteriology, 7th ed., the Williams and Wilkins Co., Baltimore (1957). 